\title{
Investigation of exhaust gas heat recovery unit for diesel power generator
}

\author{
Ibrahim Alhajjar ${ }^{1}$, Houssein Al Moussawi ${ }^{2}$, and Farouk Fardoun ${ }^{1, *}$ \\ ${ }^{1}$ University Institute of Technology, Department GIM, Lebanese University, Saida, Lebanon \\ ${ }^{2}$ Lebanese International University, MENG Department, Beirut, Lebanon
}

\begin{abstract}
The aim of this paper is to find a proper heat recovery unit that recovers lost energy from a diesel power generator exhaust. This process is performed by inserting the exhaust gas of a $20 \mathrm{kVA}$ power generator into a specifically configured shell \& tube exchanger, and transferring its energy into circulating water. The carried energy is then stored in a thermal storage tank so that it would be used for a selected residential energy demand. This method is called "cogeneration". Different configurations of heat exchanger and tank volumes are considered and flow simulations are performed in order to select a suitable recovery unit for the given design conditions.
\end{abstract}

\section{Introduction}

Cogeneration or combined heat and power (CHP) production is the use of a heat engine or power station to simultaneously generate electricity and useful heat, where both heat and power requirements are satisfied from a single fuel source [1]. Cogeneration systems may vary in type and can be driven using different prime mover technologies such as gas turbines, steams turbines, or internal combustion engines [2], as shown in Fig.1. In a gas turbine system air is compressed and burned with injected fuel (natural gas) in order to drive a power producing turbine. This system is widely used due to its significantly high temperature heat output [3]. In a steam turbine system that runs on Rankine cycle, water is pressurized and superheated to form steam that drives the turbine to generate power. This system is widely used in thermal power plants [4]. In a reciprocating system, piston engine is used where chemical energy from internal combustion is converted into mechanical energy in the crankshaft, which in turns drives the electrical power generator. Such units are widely used as backup in Lebanon due to regular electricity cuts, and mostly use diesel power generators [5]. The heat output of such systems which would be lost otherwise, is recovered in a cogeneration system to cover other energy demands such as domestic hot water, space heating, or an industrial or mechanical process [6]. One vital tool of heat recovery are heat exchangers; defined as devices that transfer energy (mainly thermal) from one fluid to another. For diesel power generators, exhaust air to water heat exchangers are usually used.

\footnotetext{
* Corresponding author: ffardoun@ul.edu.lb
} 


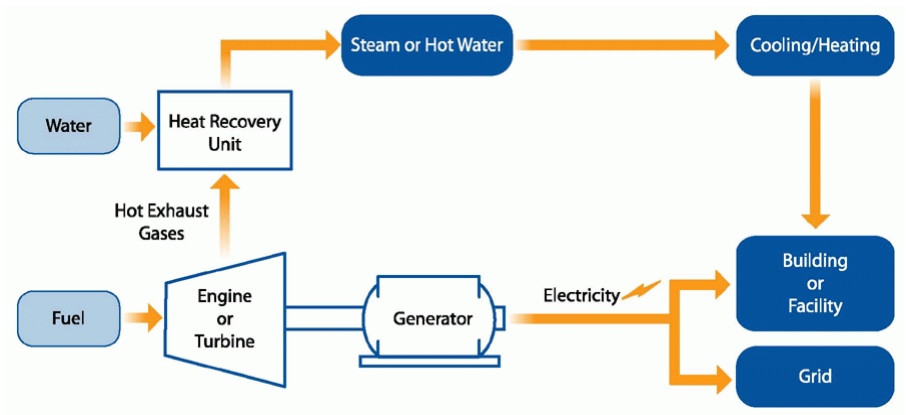

Fig. 1. General concept of a cogeneration system

\section{Method}

A design for the heat exchanger is selected and applied. More specifically, a shell and tube type counter current heat exchanger is designed, where water flows inside the tubes and exhaust air flows in the shell of the exchanger. Such types are widely used in water-air heat transfer applications [7]. Then different configurations for the heat exchanger are considered by changing the number of inlet or outlet ports for air and water, or by adding fins. Necessary analysis is then carried out using flow simulations platform of SolidWorks that allows viewing the detailed flow of the fluids in the exchanger with their corresponding temperatures, pressures, and other parameters. Observation data is used for applying the effectiveness method, in order to find the most appropriate heat exchanger for the design conditions (a $20 \mathrm{kVA}$ diesel power generator supplying a conventional residential unit). A heat storage tank is finally added to complete the recovery unit, and Trnsys software is used to obtain the transient temperature of water in tank, supposedly needed for domestic hot water usage, and conclude the best required tank volume. In fact, three different heat exchanger configurations were studied as follows:

A. Two inlet ports (one for water and one for air)/ two outlet ports (one for water and one for air)

B. Three inlet ports (one for water and two for air)/ three outlet ports (one for water and two for air)

C. Four inlet ports (one for water and three for air)/ two outlet ports (one for water and one for air) and adding fins or baffles

A schematic of the third configuration (C) with a view of the corresponding fins positions is shown in Fig.2. The effectiveness method used in calculations necessitates determining the maximum possible heat transfer rate that can be hypothetically achieved, and the actual heat transfer occurring between either fluids. Derivations of the equations of the effectiveness method are given as:

$$
\begin{gathered}
Q_{\max }=C_{\min }\left(T_{h, i}-T_{c, i}\right) \\
Q=\dot{m}_{h} C_{h}\left(T_{h, i}-T_{h, o}\right)=\dot{m}_{c} C_{c}\left(T_{c, o}-T_{c, i}\right) \\
\varepsilon=Q / Q_{\max }
\end{gathered}
$$

where; $Q$ is the actual heat transfer rate, $Q_{\max }$ is the maximum heat that could be transferred between the fluids, $C$ is the heat capacity rate, $C_{\min }$ is the lowest heat capacity rate between the two fluids, $T$ is the temperature of the fluid, $\varepsilon$ is the effectiveness of the heat exchanger, and the subscripts $h, c, i$, and $o$ corresponds to hot, cold, in, and out respectively. 
Parameters of the hot gases flow are extracted from real diesel generator data sheets of the equivalent power output. Such data sheets provide the flow rate and temperature of the exhaust gases of the diesel engine, which are to be supplied to the hot side of the heat exchanger. On the other side (cold side) of the heat exchanger, the cold water is supposed to be entering at tap water temperature given from weather data for the corresponding region of the system setup. Its flow rate is adjusted as to be sufficient for supplying domestic use water for a standard Lebanese family. Same parameters are used for all considered heat exchanger configurations to make proper comparisons. Inlet pressures at both sides are also taken into consideration. The water is supposedly entering at a pressure slightly greater than the atmospheric. Remaining parameters are either fluid constants, heat exchanger geometry related, or determined by the simulation process.
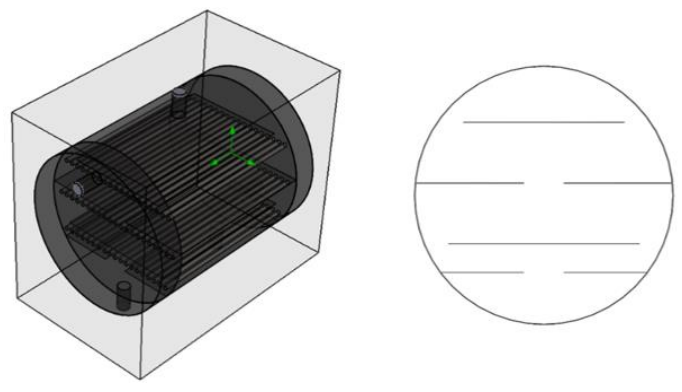

Fig. 2. Configuration $\mathrm{C}$ of the designed heat exchanger and the relative fins positions

\section{Results}

For each of the three heat exchanger configurations, the flow is simulated and recorded as shown in Fig.3, aiming to find the best flow pattern that leads to the best heat transfer between the exchanger fluids. The simulations show that adding ports for exhaust air inlets can enhance the heat transfer to water by directing more air through the water tubes and thus more contact areas. However, adding the fins proved to be more significant since they forced the flow of air over the preferred areas in the heat exchanger shell, which are the water tubes contact areas. In fact, Configuration (C) showed to have the least back pressure of water (643.61 Pascal), and the maximum effectiveness value of 0.57 . Tabulated values of the obtained results are shown in Table 1.

Table 1. Data obtained for the considered heat exchanger configurations

\begin{tabular}{|c|c|c|c|}
\hline & Configuration (A) & Configuration (B) & Configuration (C) \\
\hline $\begin{array}{c}\text { Water back Pressure } \\
\text { (Pascal) }\end{array}$ & 769.4 & 784.02 & 643.61 \\
\hline Effectiveness (-) & 0.31 & 0.37 & 0.57 \\
\hline
\end{tabular}

As the best configuration of the heat exchanger is realized, a thermal storage tank would be vital in order to store hot water for later domestic use. The storage tank together with the heat exchanger constitutes the heat recovery unit. In order to find the best volume for the tank, two parameters are taken into account: application and design condition. The application of the recovered heat is domestic hot water use, which means that the temperature of the water must be tolerable to the human body, and thus a $50^{\circ} \mathrm{C}$ temperature would be perfect. Also, the system is supposed to run during electrical grid cuts, which are regularly every 4 hours. Therefore, a range of tank volumes is considered and transient data 
of temperature is recorded as presented in Table 2. It is shown that the $1 \mathrm{~m}^{3}$ tank is the best option for this specific application.

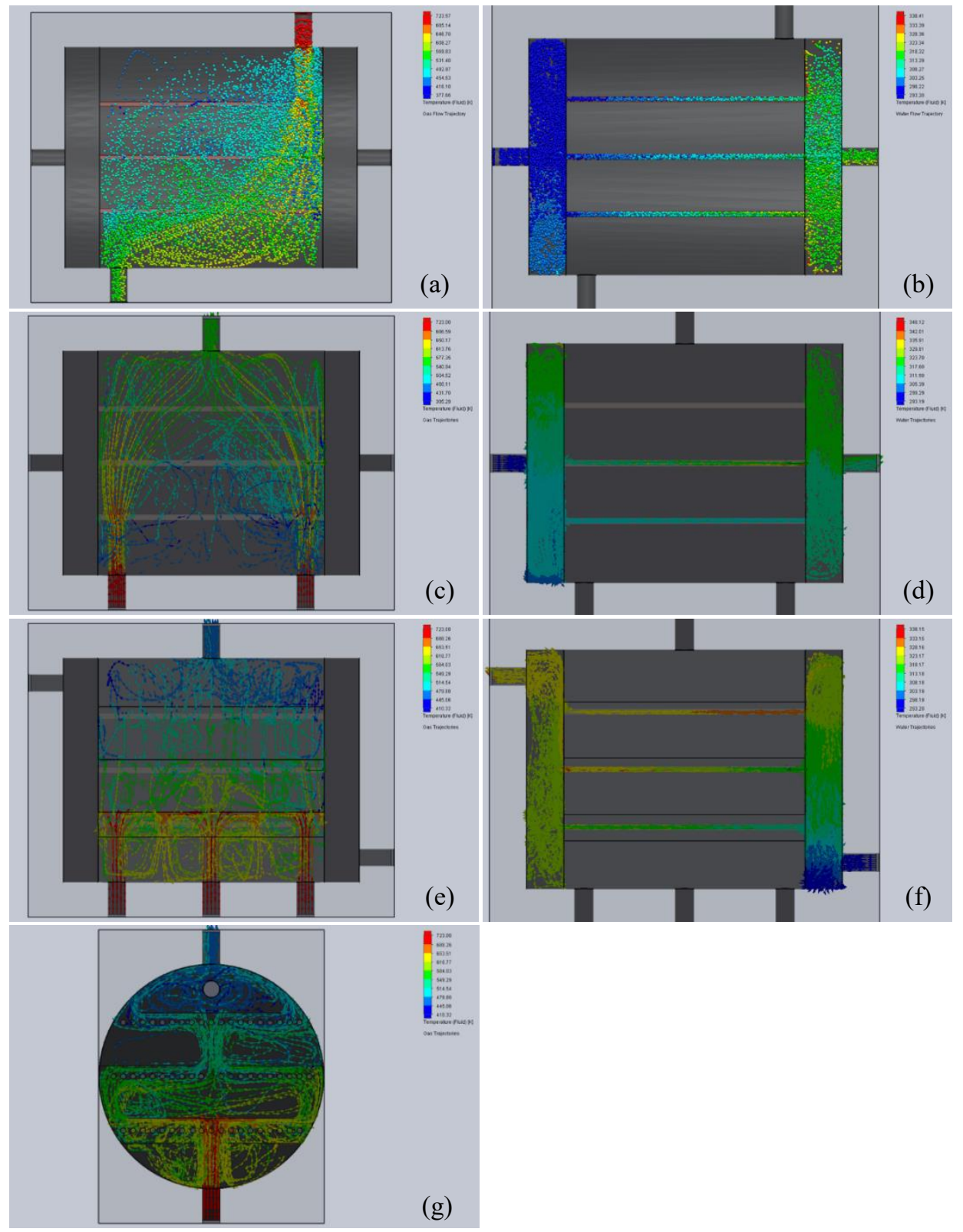

Fig. 3. Flow simulation for configuration $A$ of (a) air in heat exchanger, and (b) water in tubes, and for configuration B of (c) air in shell, and (d) water in tubes, and for configuration C of (e), (g) air in shell, and (f) water in tubes, using SolidWorks animations 
Table 2. Transient storage tank water temperatures for different tank volumes

\begin{tabular}{|c|c|c|c|c|c|}
\hline Tank Volume $\left(\mathrm{m}^{3}\right)$ & 0.5 & 0.75 & 0.9 & 1 & 1.25 \\
\hline Time (hours) & \multicolumn{5}{|c|}{ Water Temperature $\left({ }^{\circ} \mathrm{C}\right)$} \\
\hline 0 & 0 & 0 & 0 & 0 & 0 \\
\hline 0.5 & 7.31 & 4.79 & 3.97 & 3.55 & 2.83 \\
\hline 1 & 21.06 & 14.05 & 11.72 & 10.54 & 8.45 \\
\hline 1.5 & 34.55 & 23.17 & 19.36 & 17.44 & 14.01 \\
\hline 2 & 47.75 & 32.16 & 26.91 & 24.26 & 19.51 \\
\hline 2.5 & 57.28 & 41.01 & 34.35 & 30.99 & 24.94 \\
\hline 3 & 62.42 & 49.73 & 41.69 & 37.64 & 30.33 \\
\hline 3.5 & 67.43 & 56.31 & 48.94 & 44.21 & 35.65 \\
\hline 4 & 72.35 & 59.71 & 55.16 & 50.69 & 40.92 \\
\hline
\end{tabular}

\section{Conclusions}

Multiple forms of energy can be produced using cogeneration technology. In this paper, it is intended to investigate a heat recovery unit for a case study, where diesel power generator is feeding a residential building with electricity. The recovered energy is to be used as domestic hot water for residents. A shell \& tube heat exchanger and a heat storage tank are selected to build the recovery unit. Different heat exchanger configurations and storage tank volumes are considered in order to find the unit that best suits the application. It was concluded that adding inlet ports for air together with proper fins positioning can significantly enhance the heat transfer in the heat exchanger. Using the effectiveness method, configuration $\mathrm{C}$ is realized to be the best with an effectiveness value of 0.57 . Also, taking into consideration the regular grid shortage, and the tolerable water temperature level to be supplied, the $1 \mathrm{~m}^{3}$ volume tank is found to be the best among the considered tanks.

\section{References}

[1] H. Al Moussawi, F. Fardoun, and H. Louahlia, "Selection based on differences between cogeneration and trigeneration in various prime mover technologies," Renew. Sustain. Energy Rev., vol. 74, pp. 491-511, Jul. 2017.

[2] H. Al Moussawi, F. Fardoun, and H. Louahlia-Gualous, "Review of tri-generation technologies: Design evaluation, optimization, decision-making, and selection approach," Energy Convers. Manag., vol. 120, pp. 157-196, Jul. 2016.

[3] F. Caresana, G. Comodi, L. Pelagalli, M. Renzi, and S. Vagni, "Use of a test-bed to study the performance of micro gas turbines for cogeneration applications," Appl. Therm. Eng., vol. 31, no. 16, pp. 3552-3558, Nov. 2011.

[4] J. H. Choi, J. H. Ahn, and T. S. Kim, "Performance of a triple power generation cycle combining gas/steam turbine combined cycle and solid oxide fuel cell and the influence of carbon capture," Appl. Therm. Eng., vol. 71, no. 1, pp. 301-309, Oct. 2014.

[5] H. A. Moussawi, M. Mahdi, F. Fardoun, and H. Louahlia-Gualous, "Recovery Storage Tank Size: An Optimization Approach for Tri-generation Systems on Diesel Power Generators," Energy Procedia, vol. 74, pp. 788-798, Aug. 2015.

[6] A. Rosato, S. Sibilio, and G. Ciampi, "Energy, environmental and economic dynamic performance assessment of different micro-cogeneration systems in a residential application," Appl. Therm. Eng., vol. 59, no. 1-2, pp. 599-617, Sep. 2013. 
[7] V. Pandiyarajan, M. Chinna Pandian, E. Malan, R. Velraj, and R. V. Seeniraj, "Experimental investigation on heat recovery from diesel engine exhaust using finned shell and tube heat exchanger and thermal storage system," Appl. Energy, vol. 88, no. 1, pp. 77-87, Jan. 2011. 